УДК 621.03:669

\title{
FLUE GASES CLEANING FROM NITROGEN OXIDES BY ADDITIONAL OXIDATION OF NO TO $\mathrm{NO}_{2}$ AND ABSORPTION
}

\author{
Sigal O.I., Paderno D.Yu. \\ Institute of Engineering Thermophysics of the National Academy of Sciences of Ukraine, 2A, M.Kapnist str., Kiev, 03057, \\ Ukraine
}

https:doi.org/10.31472/ttpe.1.2020.9

Проведені експериментальні дослідження експлуатаційних характеристик лабораторних зразків двох типів насадки для контактного теплоутилізаційного апарата -3 використанням керамічних кілець Рашига та розробленої конструкції 3 використанням стрічки аморфно-го металевого сплаву. Показано, що металева насадка дещо перевищує керамічну за основними теплотехнічними параметрами, та сприяє доокисленню $\mathrm{NO}$ до розчинного у воді $\mathrm{NO}_{2}$, що дозволяе видалити більшу кількість останнього шляхом абсорбції водою і в результаті зменшити викиди оксидів азоту у довкілля після контактного апарата на 35 \% більш ефективно, ніж при використання керамічної насадки

Проведены экспериментальные исследования эксплуатационных характеристик лабораторных образцов двух типов насадки для контактного теплоутилизационного аппарата - с использованием керамических колец Рашига и разработанной конструкции с использованием ленты аморфного металлического сплава. Показано, что металлическая насадка несколько превышает керамическую по основным теплотехническим параметрам, и способствует доокислению $\mathrm{NO}$ до растворимого в воде $\mathrm{NO}_{2}$, что позволяет удалить большее количество последнего путем абсорбции водой и в результате уменьшить выбросы оксидов азота в окружающую среду после контактного аппарата на 35 \% более эффективно, чем при использовании керамической насадки.
Experimental researches of operational characteristics of laboratory samples of two types of packing for the direct contact heat exchanger have been carried out, - Raschig ceramic rings and the developed construction with using the ribbon of amorphous metal alloy. The metal alloy packing slightly surpasses the ceramic one by the basic operational heat engineering parameters, and contributes to oxidation of the $\mathrm{NO}$ to water-soluble $\mathrm{NO}_{2}$, which enables to remove more of the latter by absorption with water and, as a result, to reduce the emissions of nitrogen oxides to the environment after contact apparatus by $35 \%$ more efficiently than with using the ceramic packing.

References 27, tables 1, figures 7.

Key words: combustion of fuel, reduction of nitrogen oxides emission, contact heat exchanger, amorphous metal alloy ribbon fill assembly, absorption.

\section{Introduction}

Reduction of emissions of toxic nitrogen oxides $\mathrm{NO}_{\mathrm{x}}$ from fuel combustion in boilers can be realized in two ways - by reducing their formation directly in the furnace processes with using the regime-technological methods, and by cleaning of flue gases after exiting from boilers [1].

The basic primary regime-technological methods allow reducing formation of the nitrogen oxides NOx, respectively: the flue gas recirculation - by $15-45 \%$, the stepped supply of air and fuel - by $40-50 \%$, the introduction of moisture into the combustion zone - by $30-40 \%$, low-emission burners - by $30-50 \%$, that is actually at most in $2 \ldots .2 .5$ times (corresponds to the so-called Frank-Kamenetsky temperature step [2]), which often does not allow emissions to be brought into line even with the currently applicable $\mathrm{NO}_{\mathrm{x}}$ emission norm in Ukraine from stationary sources (500 $\left.\mathrm{mg} / \mathrm{m}^{3}[3,4]\right)$. More effective reduction of $\mathrm{NO}_{x}$ emissions requires the use of methods for cleaning gas emissions from nitrogen oxides (application of selective catalytic reduction technology (SCR - emission reduction by $80-98 \%$ ) or selective non-catalytic reduction (SNCR - reduction by $30-50 \%$ ).

\section{Problem}

In accordance with Ukraine's obligations under the EU-Ukraine Association Agreement, the requirements of EU environmental directives should be implemented in the country, in particular for combustion plants with a nominal input thermal capacity exceeding $50 \mathrm{MW}$ - the Directive 2010/75/EU "On industrial emissions (integrated pollution prevention and control)" [5], which sets the emission limit values for NOx for such gas boilers at $100 \mathrm{mg} / \mathrm{m}^{3}$. The percentage of such powerful boilers in the country is small about $1.5 \%$ of the total number of installed boilers in heat supply systems, however the contribution made by them to heat energy production reaches about $60 \%$ of the total value, with the corresponding contribution to the total amount of nitrogen oxides emissions. 
For 137 such large combustion plants, the limited operation terms are set, and 90 more are included in the National Emission Reductions Plan (NERP) [6], according to which the period of implementation of the requirements for $\mathrm{NO}_{\mathrm{x}}$ emission reductions due to the high complexity and cost of implementing of the appropriate measures (the cost of a modern nitrogen oxides cleaning installation is $50 \ldots 90 \mathrm{USD} /$ $\mathrm{kW}$ of installed capacity [7]), is prolonged until December 31,2033 , but with mandatory annual reduction of emissions of pollutants according to the plan.

As to combustion plants with capacity of less than $50 \mathrm{MW}$, Ukraine has not yet assumed the obligation to further limit the concentration of pollutants in combustion products to European standards. However, it should be expected that in the process of further progress towards European integration, Ukraine will have to meet the requirements of other, besides the directly specified in the Association Agreement, EU regulatory documents, including the Directive (EU) 2015/2193 of 25.11.2015 "On the limitation of emissions of certain pollutants into the air from medium combustion plants" [8], which has already entered into force in the EU.

This Directive regulates emissions of pollutants from combustion of fuels at installations with a rated thermal input from $1 \mathrm{MW}$ to $50 \mathrm{MW}$ ("medium combustion plants") and is in fact complementing and further spreading the requirements of Directive 2010/75/EU for medium combustion plants; together these two directives cover about $90 \%$ of the production capacities of district heating enterprises in Ukraine.

According to the requirements of Directive (EU) $2015 / 2193$, the limit values of nitrogen oxides concentrations in flue gases under combustion of natural gas in particular are 250 and $100 \mathrm{mg} / \mathrm{m}^{3}$ for existing and new plants, respectively.

The specific cost of an installation for nitrogen oxides cleaning for medium combustion boilers is even higher than for the large-capacity boilers, therefore installation of such units for district heating enterprises in present conditions is an extremely heavy economic load.

The temperature of the flue gases at the outlet of boilers, in particular of medium capacity that are mostly not equipped with developed convection surfaces, is usually $160 \ldots 180{ }^{\circ} \mathrm{C}$ and higher, which was previously considered acceptable due to the low cost of fuel and to the conditions for preventing condensation of moisture in the flue pipes, however this causes significant losses of fuel energy (about $1 \%$ for every $20{ }^{\circ} \mathrm{C}$ of flue gas temperature). In addition to fuel overrun, the high-temperature gas emissions cause thermal pollution of the environment.
In order to reduce the temperature of the flue gases, beyond boiler outlet the heat utiliser is often installed. The most economically reasonable is to install condensing apparatus, in which cooling of the flue gases below the dew point is realised, that allows to utilise, in addition to the physical heat of the gases, the heat of condensation of water vapor formed during combustion of fuel as well.

Combination of the deep utilization of the heat of flue gases and absorption cleaning of gas emissions from nitrogen oxides in one apparatus, moreover with the additional possibility of humidifying the blown air with using the contact air heater, will allow both to increase energy efficiency of fuel using in boilers, and to reduce emissions to the atmosphere.

However, such combination is complicated task, since the optimal conditions for these two processes are practically the opposite: the solubility of gases increases at low temperatures, while the efficiency of heat taking off increases at high temperatures. In the framework of the traditional ideology of the contact chamber of an apparatus, solution of this problem is not possible.

\section{Purpose of the work}

The purpose of this work is additional to the possibilities of the regime-technological methods reduction of emissions of nitrogen oxides during combustion of fuels, primarily of natural gas, with high intensity of utilization of the flue gases' heat with application of the contact heat exchangers.

The immediate task is to develop the packing assembly with an amorphous metal ribbon to intensify the oxidation reactions of $\mathrm{NO}$ to $\mathrm{NO}_{2}$, followed by absorption of the latter with water in a contact heat utilizer.

\section{Background}

The share of highly toxic nitrogen dioxide $\mathrm{NO}_{2}$ (maximum permissible concentration (MPC) of $\mathrm{NO}_{2}=$ $\left.0,085 \mathrm{mg} / \mathrm{m}^{3}\right)$ [9]) of the total concentration of nitrogen oxides in flue gases of boilers is small, usually $4 . . .8 \%$ [10]. At the same time, nitrogen dioxide is readily soluble in water, and can be easily removed in this way, whereas the solubility of the less toxic nitric monoxide (MPC of $\mathrm{NO}=$ $0.4 \mathrm{mg} / \mathrm{m}^{3}$ [9]) is significantly lower and is $7.38 \mathrm{ml} / 100 \mathrm{~g}$ at $0{ }^{\circ} \mathrm{C}$, decreasing with increasing temperature $(2.6 \mathrm{ml} / 100 \mathrm{~g}$ at $\left.100{ }^{\circ} \mathrm{C}\right)$ [10].

Emissions of nitrogen oxides are converted to $\mathrm{NO}_{2}$, since it is believed that under the influence of solar radiation in the atmosphere, the total oxidation of $\mathrm{NO}$ to $\mathrm{NO}_{2}$ is realized. However, during the time of the gas flow inside an apparatus at its usual velocities of $2 \ldots 4 \mathrm{~m} / \mathrm{s}$, only about $1 \%$ of NO has time to oxidize. In general, this is a positive factor, since the total toxicity of nitrogen oxide emissions at 
the time of their release from the equipment is several times less than estimated, but later in the atmosphere it oxidizes to $\mathrm{NO}_{2}$.

The cheapest method of flue gas cleaning from nitrogen oxides is absorption cleaning with the use of conventional water in heat utilization apparatuses, which are now increasingly used for reasons of permanent growth of fuel costs, and more stringent environmental requirements.

Unlike other known methods for reducing nitrogen oxide emissions, which are only costly, require permanent operating costs and in many cases reduce efficiency of boilers, such technology not only does not reduce the efficiency of boilers, but also enables to save fuel and due to this is self-sufficient.

In accordance with the Law of Ukraine "On heat supply" [11], implementation of the flue gas heat utilizers is attributed to the main directions of the development of heat supply systems (Article 7), and the draft Law of Ukraine "On Amendments to the Law of Ukraine on Heat Supply" has been developed for the prohibition of heat pollution of the atmosphere, which in particular provides for the prohibition of the use of new or reconstructed plants burning natural gas or biofuels, that have the thermal capacity of $3.15 \ldots 50 \mathrm{MW}$ and form flue gases at temperatures over $60{ }^{\circ} \mathrm{C}$, without heat recovery of the flue gases. Such requirements meet modern European standards.

The utilized heat is expedient to use in heat supply systems for preheating the return water of heating networks and for heating the blown air for boilers. At the same time, the fuel consumption coefficient can be really increased by $6 . .10 \%$.

The utilization of flue gases' heat is most effective when cooled to a temperature below the dew point of water vapor contained in gases; in such case not only the physical heat of the gases is utilized, but also the heat of condensation of water vapor contained in them (approximately $11 \%$ ). In order to realize the application of this principle, condensation heat recovery technologies and related equipment have been developed, e.g. in Sweden, Denmark, Lithuania, Russia and Ukraine. In the former USSR, developments were started at the Leningrad Engineering and Construction Institute, Kyiv Institute for Sanitary Engineering (DNIIST) and continued at the Institute of Engineering Thermophysics of the National Academy of Sciences of Ukraine, the Kyiv Polytechnic Institute, the Kyiv Engineering and Construction Institute, the Institute of Engineering Ecology, etc.

In addition to direct utilization of the flue gases' heat and the associated benefits, application of the heat utilization technologies also enables to reduce emissions of harmful substances $\left(\mathrm{NO}_{x}, \mathrm{CO}\right.$ and others) and gases with a greenhouse effect $\left(\mathrm{CO}_{2}, \mathrm{H}_{2} \mathrm{O}\right)$ into the environment.
The principle of operation of contact heat exchangers is to heat the liquid heat carrier (usually water) by the hot combustion products under direct contact with them. The heating surface in contact apparatuses is the surface of the film, droplets and streams of water, through which the heat exchange between the gases and water takes place.

To improve the heat transfer conditions, the internal volume of an apparatus is filled with a special packing, construction of which should contribute to increasing the intensity of heat and mass transfer processes in the apparatus.

Material, element design and packing layer organization must provide high heat exchange and operational performance: have the most developed surface, large specific surface area, minimal aerodynamic resistance, high corrosion resistance, durability, endurance, sufficient strength, small weight, simplicity of installation works, etc.

As a packing, most often are used ceramic, plastic or metal products of various random or regular configurations (Raschig or Pall rings [12], Berl or Intalox saddles [13], etc.), various mesh packings (Spraypack, conical-type Stedman, Sulzer and other $[14,15,16,17]$, including developed in the Kiev Polytechnic Institute by N.A.Dykiy and colleagues $[18,19]$.

The analysis of constructions of contact heat and mass exchange equipment carried out in [20] has showed the priority of apparatuses with regular packing, including flatparallel, corrugated sheets, perforated sheets, bulk packings of various types from metal, ceramics, metal ceramics, e.a.

The simplest version of a flat-parallel packing is vertical packet of flat or wavy metal sheets. Typical distance between sheets is $10 \ldots 15 \mathrm{~mm}$, an increase of this size leads to decrease of the heat transfer efficiency, and decrease of it - to the sharp increase in aerodynamic resistance of the packing layer.

The limiting factors for the efficiency of cleaning out of nitrogen oxides in contact heat utilization apparatuses are the water temperature and the surface area of the absorption. Increasing of the heat utilization efficiency (i.e., increasing of the temperature of the heat carrier - water) leads to decrease of solubility; the area of the absorption surface is limited by the size of the apparatus. In view of these factors, for increasing the degree of removal of nitrogen oxides from flue gases, the authors have applied an alternative to the conventional approach - to increase the proportion of highly soluble $\mathrm{NO}_{2}$, despite some increase in toxicity at the initial moment.

This paper presents the results of experimental study of the efficiency of reducing nitrogen oxide emissions due to $\mathrm{NO}$ oxidation to $\mathrm{NO}_{2}$ followed by absorption of the wellsoluble $\mathrm{NO}_{2}$ with water in a contact heat recovery apparatus with an amorphous metal ribbon packing assembly. 


\section{Research Methodology}

As a material for manufacturing of packing for contact apparatus, it is proposed to use the amorphous metallic alloys (AMA) that are produced by ultrarapid quenching of the melt in form of ribbons with thickness of $30 . . .50 \mu \mathrm{m}$ [21] (Fig. 1). The iron based AMA, in contrast to conventional crystalline alloys, are characterized by an unique complex of physical and chemical properties, in particular from the point of view of the tasks of this work - the high strength and wear resistance, corrosion resistance, etc. [22], as well as high chemical surface activity on oxidation-reduction reactions [23].

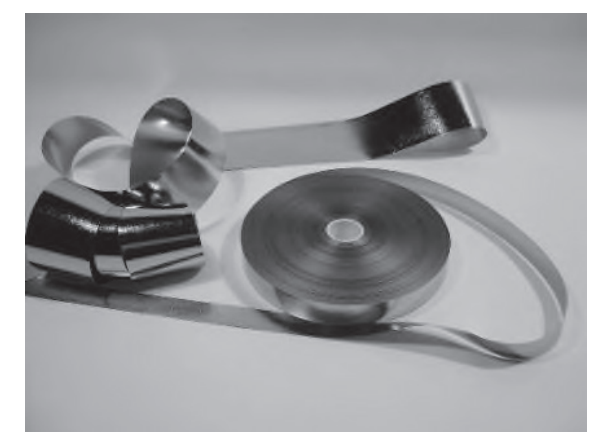

Fig. 1. Amorphous alloy ribbon

Based on the results of experiments carried out with taking into account the tendencies of the effect of alloying elements, the composition of amorphous alloys was developed which in particular meets the combination of requirements to the material of the packing [24 - 26]. The composition of the alloys includes $\mathrm{Fe}, \mathrm{Ni}, \mathrm{Cr}, \mathrm{Nb}, \mathrm{V}, \mathrm{La}$, $\mathrm{Si}$ and $\mathrm{B}$, with increased Ni content up to $20 \%$ to provide the necessary corrosion resistance in the acidic medium and the processability of production of the rapidly quenched ribbons.

Production of the amorphous metal ribbons was carried out according to the technology described in [27].

The study of the operational characteristics of packings was carried out with using the experimental stand (Fig. 2). Atmospheric air for combustion is fed by a blower fan to the contact air heater, and then through the separator - to the KS-TG-12.5 boiler. Fuel - propane-butane mixture - is mixed in the burner device with the air heated and humidified in the contact air heater, and is burned in the boiler's fire chamber. Combustion products are fed through the water condensate collector to the contact heat utilizer, the essential element of which is changeable block packing, and then to the separator and through the chimney to the atmosphere.

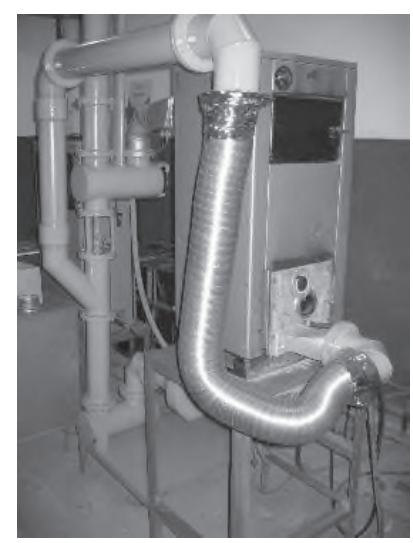

Fig. 2. Experimental stand

Experiments were carried out with two types of packing:

1) standard ceramic Raschig rings;

2) ribbon packing made of amorphous metal alloy.

The laboratory sample of the amorphous metal ribbon packing assembly for laboratory tests was made in the form of stainless steel framework of $200 \mathrm{~mm}$ in height and $100 \mathrm{~mm}$ in diameter, with an amorphous metal ribbon of $20 \mathrm{~mm}$ wide and $40 \mu \mathrm{m}$ in thickness (Fig. 3) mounted therein. The geometry of ribbons in the direction of the gases flow was the zigzag-like shape of the flat-parallel packing, corrugated with curve of corrugations at an angle of about 120 degrees, alternately with a displacement by half of the period in opposite directions in adjacent ribbons. The alternation of diffuser and confuser zones turbulates the gas flow and promotes the increase of heat transfer efficiency. In addition, such form is less sensitive to uneven irrigation, as the resulting jet breaks cause dominating of formation of the jet-drip motion of the liquid phase, which, in the absence of good wettability that is typical to metal surfaces, has an advantage over the film type motion.

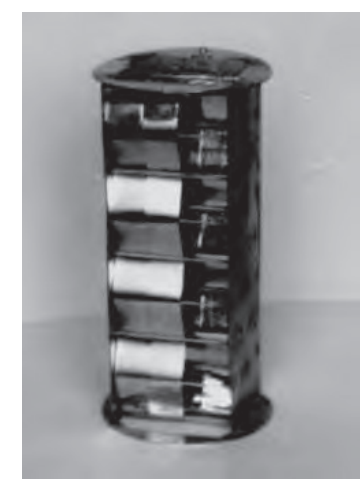

Fig. 3. Laboratory sample of amorphous metal ribbon packing (side wall is removed) 
The distance between the surfaces of ribbons was about $17 \ldots 20 \mathrm{~mm}$. An increase of this size leads to decrease of the aerodynamic resistance of the packing layer and to the de-intensification of heat transfer, and decrease to less than $7 \ldots 10 \mathrm{~mm}$ leads to the excessive growth of resistance, while in some places under uneven flow of liquid the films of adjacent ribbons may connect, and in these places the film apparatus turns into the bubble one. From the point of view of heat exchange, this would lead to significant increase of efficiency, but aerodynamic resistance would increase many times, and the process would be extremely uneven.

Optimization of the distance between the ribbons depends on the critical velocity in the packing layer, which is the limit in terms of providing the normal hydrodynamic regime without flooding and removal of significant amounts of fluid from the packing.

\section{Results and Discussion}

Study of the heat exchange efficiency between combustion products and the irrigation fluid (water) in the contact chamber was carried out under two main operating modes of the boiler, at which the temperature of the combustion products at the boiler outlet was about $150{ }^{\circ} \mathrm{C}$ and $250{ }^{\circ} \mathrm{C}$, respectively. The water temperature at the entrance to the contact chamber was $12 \ldots 24{ }^{\circ} \mathrm{C}$.

The depth of cooling of the combustion products significantly depends on the irrigation coefficient, while the difference in the reduction of temperature of the flue gases passing through the ceramic packing and the metal ribbon packing is small $-3 \ldots 4{ }^{\circ} \mathrm{C}$ (Fig. 4). The deeper cooling of combustion products may be expected with an irrigation factor of more than $6 \mathrm{~kg} / \mathrm{kg}$ of dry gases, but in this range the dependence is expressed significantly weaker, and the rise of water temperature at the outlet from the contact chamber becomes much smaller (Fig. 5). Thus, the irrigation coefficient range of $3 . . .5 \mathrm{~kg} / \mathrm{kg}$ d.g. may be considered the most expedient in terms of the balance of the temperature potential and the amount of heated water.

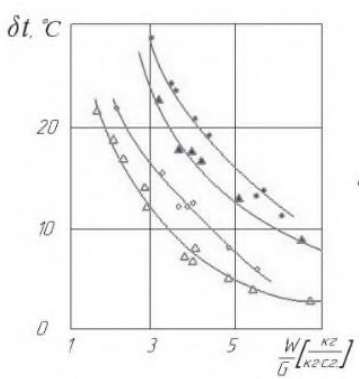

$a$

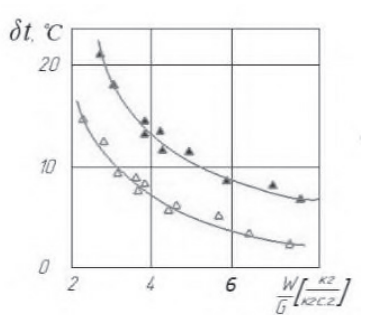

$b$
Fig. 4. Dependence of the temperature difference of the gas at the outlet of the contact chamber and the water at the inlet to it on the irrigation coefficient

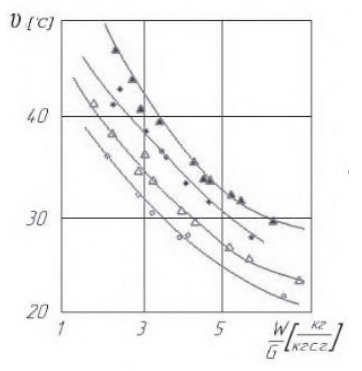

$\boldsymbol{a}$

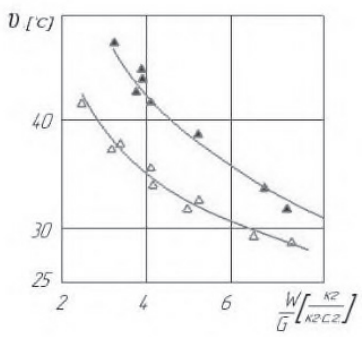

b
Fig. 5. Dependence of the temperature of water at the outlet of the contact chamber on the irrigation coefficient Initial water temperature: a) $12 \ldots 13^{\circ} \mathrm{C}$; b) $20 . .22^{\circ} \mathrm{C}$.

1, 2 - initial temperature of combustion products up to $150^{\circ} \mathrm{C}$; 3, 4 - initial temperature of combustion products up to $250^{\circ} \mathrm{C}$. 1, 3 - amorphous metal ribbon packing,

2, 4 - ceramic packing.

$\triangle$ - $1, \bigcirc-2, \triangle-3, \bigcirc-4$

Dependences of the aerodynamic resistance of the amorphous metal ribbon and ceramic Raschig ring packings on the irrigation mass density and the combustion products velocity are shown at Fig. 6.

The point of inflection on the graphs at Fig. 6 corresponds to the value of irrigation density $\mathrm{H}$, at which the complete wetting of the packing surface is achieved. With further increase of $\mathrm{H}$ its influence on the resistance of packing decreases.

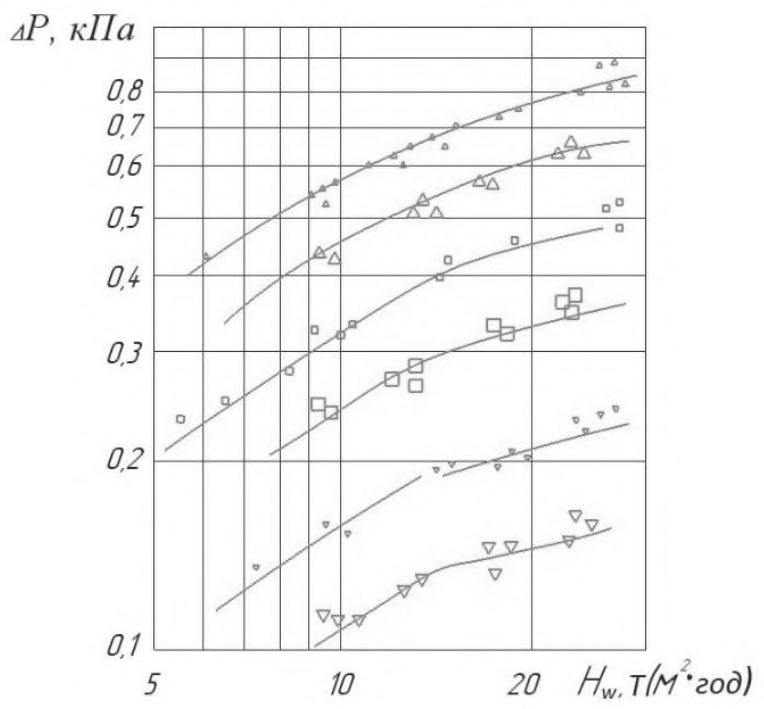

Fig. 6. Dependence of the aerodynamic resistance of the packing on the irrigation density and the combustion products velocity:

$\triangle-1, \square-2, \nabla$-3 - amorphous metal ribbon packing, $\triangle-4,-5, \nabla-6$ - ceramic packing. 1 and 4, 2 and 5, 3 and 6 - the velocities of the combustion products, respectively: $1.8 \ldots 2.0 \mathrm{~m} / \mathrm{s}, 1.4 \ldots 1.6 \mathrm{~m} / \mathrm{s}, 0.9 \ldots 1.1 \mathrm{~m} / \mathrm{s}$. 
Aerodynamic resistance of the ceramic packing at irrigation density of $22 \ldots 23 \mathrm{t} /\left(\mathrm{m}^{2} \mathrm{~h}\right)$ and the combustion products velocity of $1.8 \ldots .2 .0 \mathrm{~m} / \mathrm{s}$ can reach the value of $0.8 \ldots 0.9 \mathrm{kPa}$, which already exceeds the expedient interval, and in this it concedes to the ribbon metal packing.

The efficiency of flue gases cleaning by absorption in contact apparatus with different types of packings was assessed by direct measurements of the concentration of nitrogen oxides in the flue gases after the contact apparatus. The results of the measurements are given in Table 1.

As it can be seen from Table 1, reduction of the nitrogen oxides emissions after the contact apparatus with using the amorphous metal ribbon packing is, in average, in absolute value by $5.4 \%$, and in relative one - by $35 \%$ more intense than with using of the ceramic packing.

Table 1. Concentration of $\mathrm{NO}_{\mathrm{x}}$ in the flue gases

\begin{tabular}{|c|c|c|c|c|c|}
\hline \multicolumn{3}{|c|}{ Ceramic packing } & \multicolumn{3}{|c|}{$\begin{array}{c}\text { Amorphous metal ribbon } \\
\text { packing }\end{array}$} \\
\hline $\begin{array}{c}\text { Before the } \\
\text { apparatus, } \\
\mathrm{mg} / \mathrm{m}^{3}\end{array}$ & $\begin{array}{c}\text { After the } \\
\text { apparatus, } \\
\mathrm{mg} / \mathrm{m}^{3}\end{array}$ & $\begin{array}{c}\text { Reduc } \\
\text { tion, } \\
\%\end{array}$ & $\begin{array}{c}\text { Before the } \\
\text { apparatus, } \\
\mathrm{mg} / \mathrm{m}^{3}\end{array}$ & $\begin{array}{c}\text { After the } \\
\text { apparatus, } \\
\mathrm{mg} / \mathrm{m}^{3}\end{array}$ & $\begin{array}{c}\text { Reduc } \\
\text { tion } \\
\%\end{array}$ \\
\hline 105 & 88 & 16 & 105 & 84 & 20 \\
\hline 110 & 89 & 19 & 112 & 85 & 24 \\
\hline 100 & 89 & 11 & 125 & 102 & 18 \\
\hline \multicolumn{2}{|c|}{ Average value } & 15,3 & \multicolumn{2}{|c|}{ Average value } & 20,7 \\
\hline
\end{tabular}

Taking into account the small thickness and, therefore, the low rigidity of amorphous alloy zibbons, it is advisable to construct packings for industrial contact heat utilizers from small separate blocks.

The separate elements - blocks of ribbon packings in industrial scale for technological reasons were made in the form of cubic frames of $240 \times 240 \mathrm{~mm}$ from the stainless steel with amorphous metal ribbon fixed inside them (Fig. 7).

Thus, the results of experimental studies have shown that the zigzag-shaped ribbon packing made from amorphous metal alloy, providing slightly more intense heat transfer, has the lower aerodynamic resistance than ceramic packing in the form of Rushig rings, that is, the first one surpasses the latter by the main operational heat engineering parameters.

Unlike ceramic and other known types of packings that do not affect the share ratio of nitrogen oxide and dioxide in flue gases, the amorphous metal alloy packing exhibits catalytic properties for $\mathrm{NO}$ oxidation to water-soluble $\mathrm{NO}_{2}$, that enables to remove more of the latter by absorption with water and, as a result, to reduce emissions of nitrogen oxides to the environment after the contact apparatus by $35 \%$ more efficiently than with using of ceramic packing.

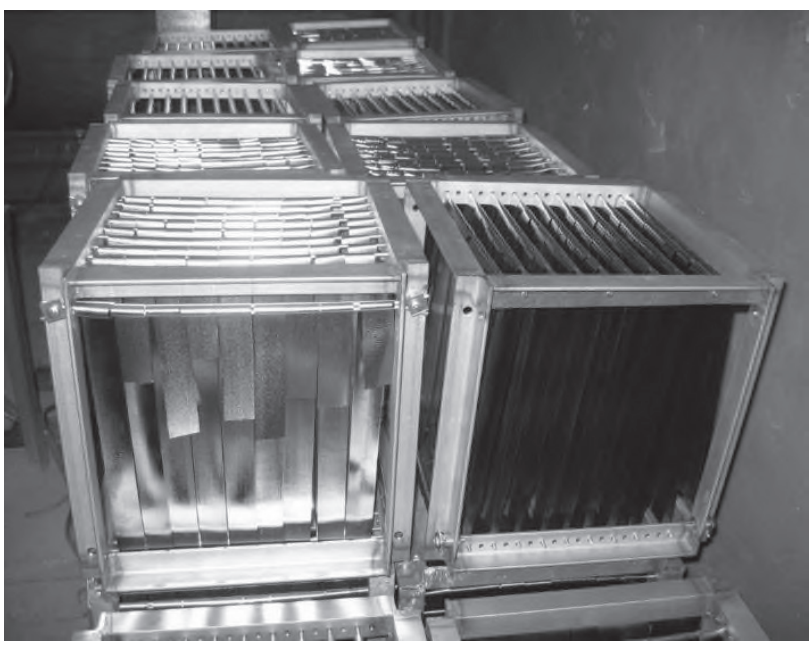

Fig. 7. Elements - blocks of ribbon packings for industrial contact heat recovery apparatus

In addition, as a result of a significant reduction in the mass and dimensions of the apparatus with packing made of amorphous metal ribbon $\left(1 \mathrm{~m}^{3}\right.$ of ceramic packing weighs about $600 \mathrm{~kg}$, and of amorphous ribbon - about $30 \mathrm{~kg}$ ), it is possible to install such apparatuses in the boiler houses, where apparatuses with ceramic packing are technically impossible to install (in small rooms, container mobile and roof boiler houses, etc.).

Implementation of contact heat utilizers with an amorphous metal ribbon packing will enable to further reduce the negative environmental impact of fuel combustion equipment, and in cases where the nitrogen oxides emissions slightly exceed the normatively permissible ones - to achieve compliance with the regulatory requirements.

\section{Conclusions}

1. The operational characteristics of laboratory samples of two types of packing for the direct contact heat utilization apparatus - with using the Raschig ceramic rings and the developed construction with using the ribbon of complex amorphous metallic Fe-Cr-Ni-Si-B system based alloy have been studied experimentally.

2. It has been experimentally shown that the zigzagshaped amorphous metal alloy ribbon packing, providing slightly more intense heat transfer, has the lower aerodynamic resistance than ceramic Rushig rings packing, that is, the first one surpasses the latter by the main operational heat engineering parameters.

3. The ribbon packing made from the amorphous metal alloy of special complex composition is experimentally shown to contribute to the NO oxidation to a water-soluble $\mathrm{NO}_{2}$, that enables to remove more of the latter by absorption 
with water and, as a result, to reduce the emissions of nitrogen oxides to the environment after the contact apparatus by $35 \%$ more efficiently than when using ceramic packing.

4. The design of the thin amorphous metal ribbon packing for the industrial contact heat recovery apparatus is developed, and elements of such packing are manufactured.

\section{REFERENCES}

1. Buryachok T.O., Butsio Z.Yu., Varlamov G.B. et al. [Electricity and environmental protection. Operation of energy in the modern world (2nd ed.)] Kyiv, 2013.390 p. (In Ukr.).

2. Frank-Kamenetsky D.A. [Diffusion and heat transfer in the chemical kinetics (3rd ed.)]. Moscow: Nauka, 1987. 502 pp. (In Rus.).

3. Order of the Ministry of Environmental Protection of Ukraine dated 27.06.2006 No. 309 [On approval of permits for pollutants from stationary sources] (In Ukr.).

4. Order of the Ministry of Environmental Protection of Ukraine dated 22.10.2008 No. 541 [On approval of technological norms for permitted emissions of pollutants from heat energy installations, the rated heat capacity of which exceeds $50 \mathrm{MW}]$. (In Ukr.).

5. Directive 2010/75/EU of the European Parliament and of the Council of 24 November 2010 on industrial emissions (integrated pollution prevention and control).

6. Volchin I.A. [Ukraine's emission reduction target in the light of the implementation of Directive 2010/75/EU on industrial emissions] Problems of ecology and operation of energy objects. [Proc. Institute of Engineering Ecology], Kyiv: IPC ALCON NASU, 2018. P. 34-38. (In Ukr.).

7. Akimov A. [Emissions], [Mirror of the week], 2013, is. 31. (In Rus.).

8. Directive (EU) 2015/2193 of the European Parliament and of the Council of 25 November 2015 on the limitation of emissions of certain pollutants into the air from medium combustion plants.

9. [State sanitary rules for protection of atmospheric air of populated areas (from pollution by chemical and biological substances]. (In Ukr.).

10. Sigal A.I. [Cleaning of gases in contact heat recovery apparatuses] Problems of ecology and operation of energy objects. [Proc. VIII conference of CIS countries], Kyiv, Institute of Engineering Ecology, 1998. P.60-67. (In Rus.).

11. [The Law of Ukraine "On Heat Supply"]. (In Ukr.).

12. Raschig products. Ref.: http://www.raschig.de/Random-Packings

13. Sainthing products. Ref.: http://www.sainthing.com/ product/intalox_saddle-en.html?gclid=EAIaIQobChMIo2M7Omw4QIVTqqaCh04VQCtEAAYASAAEgImS_D_ $\mathrm{BwE}$
14. Barton S.A. Fill Material for Direct-Contact Heat/ Mass Exchangers. Patent PCT/US2014 / 051766, US, 2014.

15. Kolev N. Packed bed columns for absorption, desorption, rectification and direct heat transfer. Elsevier B.V., The Netherlands, 2006. 687 p.

16. Sulzer products. Ref.: https://www.sulzer.com/en/ products/separation-technology/structured-packings

17. Shorland F.B. A simple helical packing for laboratory fractionating columns / Journal of Applied Chemistry, 2007. V.2, 8. P. 438-440.

18. Dykiy N.A. [Packing]. Aut. cert. USSR No. 665181, 1979. (In Rus.).

19. Dykiy N.A., Koloskova N.Yu., Bykov S.I., Chavuser M.Sh.. [Device for utilizing the heat of exhaust gases] Aut. Cert. USSR No. 14956207, 1989. (In Rus.).

20. Agapov A.V. et al. [Analysis of the possibility of using modern designs of mass-exchange contact devices under oil degassing conditions], [Moscow Scientific Review], 2011. No. 10 (14). (In Rus.).

21. Maslov V.V., Paderno D.Yu. [Manufacturing of amorphous metal alloys]. In: Amorphous Metallic Alloys, Kyiv: Naukova Dumka, 1987. P. 52-86. (In Rus.).

22. Zolotukhin I.V. [Physical properties of amorphous metallic materials]. Moscow: [Metallurgy], 1986. 176 p. (In Rus.).

23. Bilyk O.M. [Kinetics of electrochemical reactions involving oxygen compounds on amorphous metallic surfaces]. Diss. Ph.D., LSU, Lviv, 1996. (In Rus.).

24. Balan V.Z., Nosenko V.K., Paderno D.Yu. et al. [Highstrength corrosion-resistant amorphous iron-based alloy]. Patent No. 3988, Ukraine, 1994. (In Ukr.).

25. Balan V.Z., Maslov VV, Paderno D.Yu. et al. [Amorphous iron-based alloy]. Patent No. 19217, Ukraine, 1997. (In Ukr.).

26. Nosenko V.K., Balan V.Z., Paderno D.Yu. et al. [Resistant corrosion-resistant amorphous iron-based alloy]. Patent No. 104983, Ukraine, 2014. (In Ukr.).

27. Maslov V.V, Nosenko V.K., Paderno D.Yu. et al. [Method of continuous casting of ribbon]. Patent No. 1304, Ukraine, 1994. (In Ukr.). 


\section{ОЧИЩЕННЯ ДИМОВИХ ГАЗІВ ВІД ОКСИДІВ АЗОТУ ШЛЯХОМ ДООКИСЛЕННЯ NO ДО NO ТА АБСОРБЦІї}

Сігал O.I., канд. техн. наук, Падерно Д.Ю., канд. фіз.-мат. наук

Інститут технічної теплофізики НАН України, вул. М.Капніст, 2A, Київ, 03057, Україна

https:doi.org/10.31472/ttpe.1.2020.9

Поєднання глибокої утилізації теплоти димових газів і абсорбційного очищення газових викидів від оксидів азоту в одному апараті, до того ж 3 додатковою можливістю зволоження дуттьового повітря при використанні контактного повітряпідігрівача, дозволить як підвищити енергоефективність використання палива в котлах, так і знизити викиди до атмосфери.

Однак таке поєднання $€$ непростою задачею, оскільки оптимальні умови для цих двох процесів практично протилежні: розчинність газів збільшується при низьких температурах, тоді як ефективність теплоз'єму збільшується при високих температурах. В рамках традиційної ідеології контактної камери апарата вирішення цієї задачі не здається можливим.

Метою цієї роботи є додаткове до можливостей режимно-технологічних методів скорочення викидів оксидів азоту при спалюванні палива, в першу чергу природного газу, при високій інтенсивності утилізації теплоти димових газів із застосуванням контактних теплообмінних апаратів.

Безпосередньою задачею $є$ розроблення насадки 3 аморфної металевої стрічки для інтенсифікації реакцій окислення $\mathrm{NO}$ до $\mathrm{NO}_{2}$ з наступною абсорбцією останнього водою в контактному теплоутилізаторі.

Проведені експериментальні дослідження експлуатаційних характеристик лабораторних зразків двох типів насадки контактного теплоутилізаційного апарата - 3 використанням керамічних кілець Рашига та розробленої конструкції з використанням стрічки складнолегованого аморфного металевого сплаву на основі системи $\mathrm{Fe}-\mathrm{Cr}-\mathrm{Ni}-\mathrm{Si}-\mathrm{B}$.

Експериментально показано, що стрічкова насадка 3 аморфного металевого сплаву при дещо більш інтенсивному теплоз'єму має нижчий аеродинамічний опір, ніж керамічна насадка у вигляді кілець Рашига, тобто перевищує останню за основними теплотехнічними параметрами.
Показано, що використання стрічкової насадки 3 аморфного металевого сплаву сприяє доокисленню $\mathrm{NO}$ до розчинного у воді $\mathrm{NO}_{2}$, що дозволяе видалити більшу кількість останнього шляхом абсорбції водою і в результаті зменшити викиди оксидів азоту у довкілля після контактного апарата на 35 \% більш ефективно, ніж при використання керамічної насадки.

Розроблена конструкція та виготовлені елементи насадки з використанням аморфної металевої стрічки для промислового зразка контактного теплоутилізаційного апарата.

Бібл. 27, рис. 7, табл. 1.

Ключові слова: спалювання палива, зниження викидів оксидів азоту, контактний теплоутилізатор, стрічкова насадка з аморфного сплаву, абсорбція.

1. Бурячок Т.О., Буиььо З.Ю., Варламов Г.Б. та ін. Електроенергетика та охорона навколишнього середовища. Функціонування енергетики в сучасному світі. Кн. 5. 2-е вид. К., 2013.-390 с.

2. Франк-Каменеикий Д.А. Диффузия и теплопередача в химической кинетике. Изд. 3-е.- М.: Наука, 1987.$502 \mathrm{c}$.

3. Наказ Мінприроди України від 27.06.2006 № 309 «Про затвердження нормативів граничнодопустимих викидів забруднюючих речовин із стаціонарних джерел».

4. Наказ Мінприроди від 22.10 .2008 р. № 541 «Про затвердження технологічних нормативів допустимих викидів забруднюючих речовин із теплосилових установок, номінальна теплова потужність яких перевищує $50 \mathrm{MBT} \gg$.

5. Directive 2010/75/EU of the European Parliament and of the Council of 24 November 2010 on industrial emissions (integrated pollution prevention and control).

6. Вольчин I.A. Завдання України щодо скорочення викидів у світлі виконання Директиви 2010/75/EU про промислові викиди. / Проблемы экологии и эксплуатации объектов энергетики. Сб. трудов. Институт промышленной экологии. - К.: ИПЦ АЛКОН НАН Украины, 2018.- С. 34-38.

7. Акимов А. Выбросы / Зеркало недели, 2013, вып.31.

8. Directive (EU) 2015/2193 of the European Parliament and of the Council of 25 November 2015 on the limitation of emissions of certain pollutants into the air from medium combustion plants.

9. Державні санітарні правила охорони атмосферного повітря населених місць (від забруднення хімічними та біологічними речовинами). 
10. Сигал А.И. Очистка газов в контактных теплоутилизационных аппаратах / Проблемы экологии и эксплуатации объектов энергетики. Тез. докл. VIII конф. стран СНГ. К.: Институт промышленной экологии, 1998.C.60-67.

11. Закон України «Про теплопостачання».

12. Raschig products. Ref.: http://www.raschig.de/Random-Packings

13. Sainthing products, Ref.: http://www.sainthing.com/ product/intalox_saddle-en.html?gclid=EAIaIQobChMIo2M7Omw4QIVTqqaCh04VQCtEAAYASAAEgImS_D_ BwE

14. Barton S.A. Fill Material for Direct-Contact Heat/ Mass Exchangers. Patent PCT/US2014 / 051766, US, 2014.

15. Kolev N. Packed bed columns for absorption, desorption, rectification and direct heat transfer. Elsevier B.V., The Netherlands, 2006.- 687 p.

16. Sulzer products. Ref.: https:/www.sulzer.com/en/ products/separation-technology/structured-packings

17. Shorland F.B. A simple helical packing for laboratory fractionating columns / Journal of Applied Chemistry, 2007. V.2, 8.- P. 438-440.

18. Дикий Н.А. Насадка. Авт.свид. СССР N665181, 1979.

19. Дикий Н.А., Колоскова Н.Ю, Быков С.И., Чавусер М.Ш. Устройство для утилизации теплоты уходящих газов. Авт.свид. СCCP N14956207, 1989.
20. Агапов A.B. и др. Анализ возможности использования современных конструкций массобменных контактных устройств в условиях дегазации нефти / Московское научное обозрение, 2011, №10 (14).

21. Маслов В.В., Падерно Д.Ю. Получение аморфных металлических сплавов. В кн.: Аморфные металлические сплавы, К: Наук.думка, 1987.-С. 52-86.

22. Золотухин И.В. Физические свойства аморфных металлических материалов. - М: Металлургия, 1986.$176 \mathrm{c}$.

23. Бильк О.М. Кинетика электрохимических реакций с участием кислородных соединений на аморфных металлических поверхностях. Дисс. к.х.н., ЛГУ, 1996.

24. Балан В.3., Носенко В.К., Падерно Д.Ю. та ін. Високоміцний корозійностійкий аморфний сплав на основі заліза. Патент № 3988, Україна, 1994.

25. Балан В.3., Маслов В.В., Падерно Д.Ю. та ін. Аморфний сплав на основі заліза. Патент № 19217 , Україна, 1997.

26. Носенко В.К., Балан В.3., Падерно Д.Ю. та ін. Резистивний корозійностійкий аморфний сплав на основі заліза. Патент № 104983, Україна, 2014.

27. Маслов В.В., Носенко В.К., Падерно Д.Ю. та ін. Спосіб безперервного лиття стрічки. Патент № 1304, Україна, 1994.

Отримано 13.02.2020

Received 13.02.2020 